\title{
Uji Stabilitas Rancangan Anchored Reaction Frame pada Pekerjaan Loading Test Off Shore
}

\section{Darmankatni S.}

Dosen D3 Teknik Sipil FTSP-ITS

email: darman@ce.its.ac.id

\begin{abstract}
ABSTRAK
Salah satu kendala yang dihadapi pada pekerjaan Loading Test off shore pada metode Counter Weight System (CWS) yang dibebani beban siklus yang cukup besar $(\mathrm{P}=650$ ton) adalah masalah gaya puntir akibat kemungkinan terjadi perbedaan deformasi pada keempat tumpuan, yang akan mempengaruhi keseimbangan struktur CWS, yang mengakibatkan runtuhnya blok-blok beton counter weight yang berpengaruh pada keselamatan manusia. Sedangkan pada metode Anchored Reaction System (ARF) adalah gaya momen dan lendutan pada Test Beam yang cukup besar yang berpengaruh pada dimensi profil Test Beam.Untuk mengatasi kedua masalah tersebut, maka akan dirancang suatu model struktur Test Beam pada metode ARF dengan struktur yang mengarah pada bentuk rangka batang dengan bahan pipa pancang yang dipakai pertama kali dalam pelaksanaan pekerjaan loading test pada dermaga peti kemas pelabuhan Tanjung Perak. Uji stabilitas Rancangan model struktur rangka ARF terhadap beban siklus sesuai Standard Test Method for Under Static Axial Compression Test ASTMD 11443-81, akan diperoleh gambaran perilaku gerak deformasi riel yang terjadi pada tiang uji $(\Delta \mathrm{ru})$, tiang reaksi $(\Delta \mathrm{rr})$, dan rangka ARF pada titik $\mathrm{D}(\delta \mathrm{Dr})$. Dari analisa perilaku deformasi pada ketiga unsur yang terkait dengan Test Rancangan model strukur ARF, pada pembebanan siklus kesatu sampai keempat rancangan struktur ARF tetap stabil $(\delta \mathrm{Dr}=0)$, dan selama proses pembebanan sampai siklus keempat pada beban $\mathrm{P}=650$ ton,deformasi yang terjadi pada struktur ARF $\delta D r=0.022 \mathrm{~mm}<-\delta D r=25 \mathrm{~mm}$, yang membuktikan bahwa struktur ARF cukup kaku. Dari uji stabilitas rancangan struktur model dapat diprediksi besarnya gaya tarik tiang pancang baja $\varnothing 711,1 \mathrm{~mm}$.
\end{abstract}

Kata kunci: Loading Test, Deformasi, Uji Stabilitas

\section{PENDAHULUAN}

Salah satu metode untuk mengetahui secara riel daya dukung batas ultimate suatu pondasi tiang pancang adalah test pembebanan atau loading test. Mengacu pada Standard Test Method for Under Static Axial Compression Test- ASTM D 11443 - 81/ 1994, ada 2 (dua) metode dalam melakukan percobaan pembebanan, yaitu:

1. Anchored Reaction Frame(ARF).

2. Counter Weight System(CWS).

Prinsip dari kedua metode tersebut yang harus diperhatikan adalah interaksi antara gaya-gaya yang ditimbulkan oleh beban axial dan deformasi pada tiang reaksi dan struktur test beam. Beban axial (P) pada Loading Test yang ditimbulkan akan menyebabkan:

1. Gaya Uplift pada tiang reaksi, momen, dan lendutan $(\delta)$ pada tengah bentang struktur meja beban untuk metode
ARF.Semakin besar beban axial $P$ yang dibutuhkan, semakin besar pula dimensi test beam untuk mengatasi momen dan lendutan ditengah bentang.

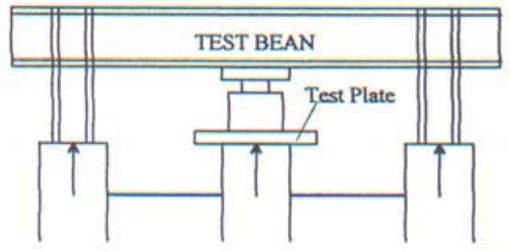

Gambar 1. Metode Anchored Reaction Frame

2. Gaya puntir pada tengah bentang, kemungkinan akibat adanya perbedaan leveling pada tumpuan yang disebabkan pembebanan berulang untuk Counter Weight System, akan mengakibatkan keruntuhan blok-blok beton (counter 
weight) yang membahayakan keamanan dan keselamatan kerja manusia.

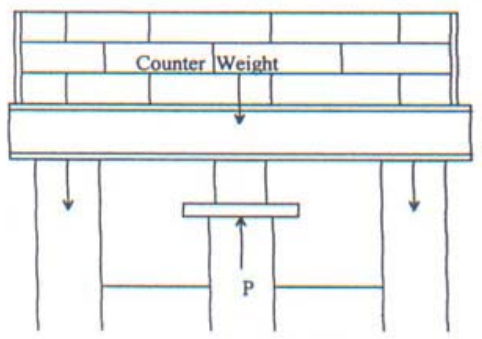

Gambar 2. Metode Counter Weight System

Pada umumnya untuk pekerjaan Loading Test off shore seperti dermaga peti kemas antar pulau di pelabuhan Tanjung Perak Surabaya yang membutuhkan daya dukung tiang pancang cukup besar senilai 325 ton, diperlukan gaya axial $(P)$ untuk beban siklus sebesar $2 \times 325$ ton = 650 ton. Untuk mengatasi pengaruh gaya uplift yang ditimbulkan oleh gaya axial $P$ yang cukup besar dan gaya puntir pada kedua metode Loading test diperlukan suatu model struktur meja beban yang dapat menjamin kehandalan strukturnya, dilihat dari unsur stabilitas, keamanan dan keselamatan kerja.

Untuk mengatasi pengaruh gaya uplift yang cukup besar dan kemungkinan keruntuhan blok-blok beton pada metode CWS, dan dimensi profil test beam melampui yang ada di pasaran pada metode ARF, maka diperlukan suatu rancangan meja beban yang dapat mengeliminir pengaruh momen, lendutan yang cukup besar di bentang tengah, dan gaya puntir pada struktur meja beban.

Dalam penelitian ini dirancang untuk pertama kali, suatu struktur meja beban untuk metode ARF dengan struktur rangka batang ruang dari pipa baja yang ditumpu pada 4 (empat) buah tiang pancang sebagai tiang angker tarik

\section{TINJ AUAN PUSTAKA}

Loading Test merupakan salah satu cara dalam menentukan daya dukung batas/ultimate suatu pondasi tiang pancang dengan beban maksimum berkisar antara $150 \%$ sampai $250 \%$ dari design load. Tujuan dilakukan pekerjaan loading test:
1. Untuk menentukan daya dukung batas tiang sebagai kontrol terhadap daya dukung yang dihitung berdasarkan formula statis atau dinamis, sehingga dapat diketahui secara riel apakah daya dukung rencana yang ditetapkan dalam perencanaan pondasi tiang cukup aman, over atau under estimate.

2. Untuk menentukan hubungan perilaku gerak antara beban dan deformasi selama beban siklus.

Pada prinsipnya loading test dilaksanakan dengan cara memberikan beban siklus pada kepala tiang pancang, dengan mengamati besarnya deformasi vertikal yang terjadi pada dial gauge yang dipasang pada tiang uji dan tiang reaksi. Deformasi yang terjadi adalah deformasi elastis yang diakibatkan oleh pemendekan elastis dari tiang dan tanah, sedangkan deformasi plastis diakibatkan runtuhnya tanah pendukung pada ujung atau sekitar tiang pancang akibat beban siklus.

Loading test dengan struktur meja beban yang diperkuat dengan tiang-tiang angker diperlukan persyaratan sebagai berikut :

1. Pekerjaan loading test dilaksanakan setelah lapisan tanah disekitar tiang pancang uji/percobaan diberi kesempatan dispasi dari excess pour water pressure akibat waktu pemancangan dan juga waktu tanah mengadakan pemulihan kembali kekuatan daya dukungnya akibat disturbance /gangguan akibat pemancangan.

2. Tiang-tiang angker/reaksi yang bekerja sebagai friction pile minimal berumur 4 (empat) minggu setelah dipancang baru bisa dibebani beban siklus. Jumlah tiang reaksi yang diperlukan tergantung pada kekuatan lapisan tanah dan besarnya beban siklus maksimum.

3. Lendutan maksimum pada bentang tengah struktur test beam dengan konstruksi rangka batang $<\delta$ t $25 \mathrm{~mm}$. Lendutan maks. $=\delta$ maks $=$

$$
\begin{aligned}
& =\sum \alpha \cdot \Delta \cdot L=\sum \alpha \cdot \frac{S \cdot L}{E \cdot A}, \\
& \text { dimana : } \\
& \mathrm{S}=\text { besarnya gaya batang }(\mathrm{kg}) \\
& \mathrm{L}=\text { panjang batang }(\mathrm{cm}) \\
& \mathrm{A}=\text { luas penampang batang }\left(\mathrm{cm}^{2}\right)
\end{aligned}
$$




$$
\begin{aligned}
& \mathrm{E}=\text { modulus elastisitas bahan }\left(\mathrm{kg} / \mathrm{cm}^{2}\right) \\
& \alpha=\text { koefisien }
\end{aligned}
$$

4. Sesuai A.S.T.M.D 1143-81, jarak bersih tiang angker (S) dan tiang percobaan/test pile atau test pile group sekurang-kurangnya 5 (lima) kali diameter maksimum test pile, tetapi tidak boleh kurang dari $7 \mathrm{ft}$ ( 2 meter).

5. Standar pembebanan Loading Test dipakai ASTM D 1143 - 81

\section{METODOLOGI}

Penelitian ini merupakan uji kestabilan struktur ARF untuk loading test, dengan mengamati deformasi yang terjadi pada struktur ARF, tiang-tiang reaksi akibat beban siklus maksimum 650 ton, sehingga dapat diperoleh gambaran perilaku kestabilan struktur ARF dan tiang angker/ reaksi selama proses beban siklus diberlakukan.Langkah-langkah dalam pelaksa-naan penelitian adalah sebagai berikut:

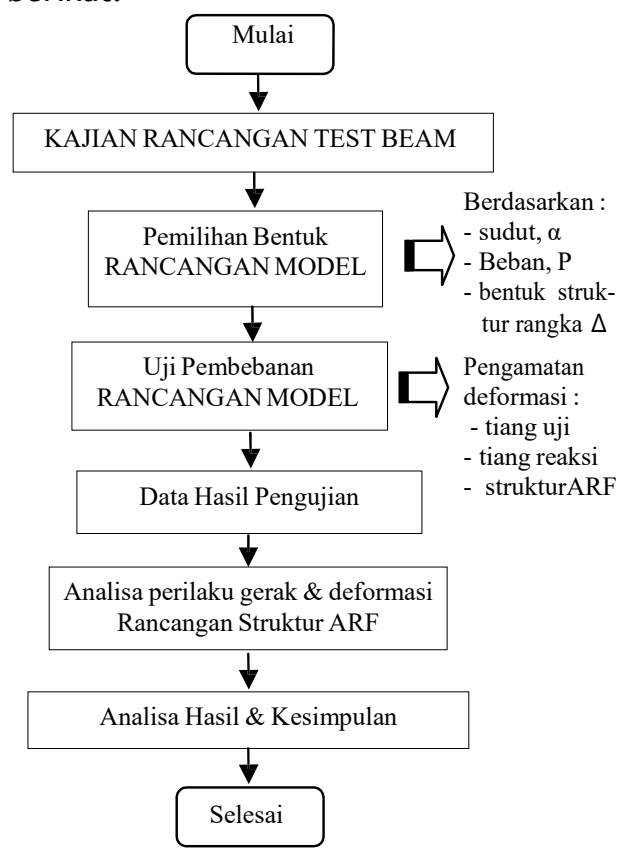

Gambar 3. Alur Metodologi

\section{RANCANGAN STRUKTUR ANCHORED REACTION FRAME}

4.1. Bentuk Struktur.

Dari penelitian yang dilakukan Wawan Witarman dari Badan Penelitian dan Pengembangan P.U Pusat Penelitian dan
Pengembangan Jalan, Juni 1995 tentang "Pengujian pondasi tiang pancang abutment I jembatan Ciamis Cirebon", yang memakai metode "Anchored Reaction Frame", dengan meja beban WF 500 x 20 yang ditahan oleh 2 (dua) buah tiang pancang angker tarik dan diperkuat dengan pelat baja pengaku dengan kapasitas tarik $2 \times 39$ ton. Ujung-ujung profil ditahan oleh batang tarik dari besi beton $3 \times 3 \varnothing 25 \mathrm{~mm}$, yang diperkuat band serta tulangan strain.

Struktur meja beban tersebut kapasitasnya relatif kecil, sehingga untuk beban 650 ton dirancang suatu struktur Anchored Reaction Frame dengan bentuk dan rancangan struktur yang mengarah pada bentuk rangka batang segitiga dengan bahan dari pipa tiang pancang baja yang ada, dan ditumpu pada 4 (empat) buah tiang reaksi, sebagai pengembangan baru. Dengan demikian, pengaruh momen dan lendutan akibat beban siklus maksimum 650 ton dapat dieliminir menjadi gaya-gaya normal tarik dan tekan yang didistribusikan pada struktur rangka batang seperti gambar berikut ini

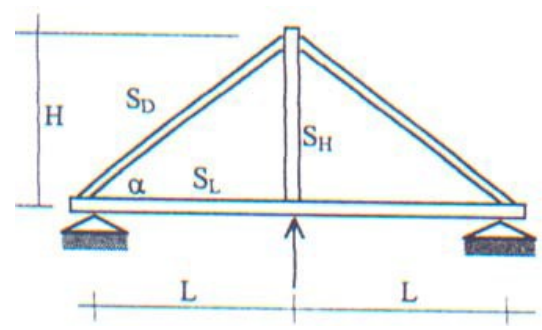

DIAGRAM CREMONA

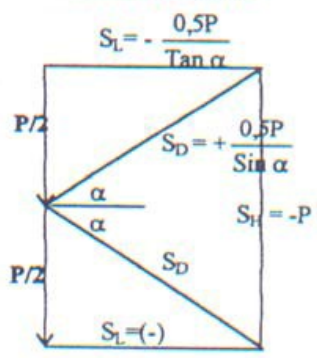

Gambar 4. Bentuk dan Diagram Cremona Meja Beban

J urnal APLIKASI: Media Informasi \& Komunikasi Aplikasi Teknik Sipil Terkini 


\subsection{Menentukan Sudut kemiringan $(\delta)$ struktur rangka meja beban.}

Untuk menentukan besaran sudut $(\delta)$ yang representatif agar ada keseimbangan dimensi batang tarik dan tekan, perlu diketahui pengaruh besaran sudut $(\alpha)$ terhadap perubahan gaya-gaya yang timbul pada masing-masing batang, maka dalam rancangan model ini dibuat 5 (lima) konfigurasi besaran sudut $(\alpha)$ bernilai $25^{\circ}$, $30^{\circ}, 35^{\circ}, 40^{\circ}, 45^{\circ}$ dan $60^{\circ}$.

Hubungan antara beban $P$ dan sudut $\alpha$, untuk menentukan sudut yang ideal untuk model struktur rangka meja beban dapat dilihat pada grafik 5 .

Dari hasil kajian diagram CREMONA pada Gambar (4) dan Grafik (5), dan pertimbangan terhadap besarnya gaya $\mathrm{Sd} \approx$ Sl dan ketinggian struktur rancangan, maka ditentukan sudut yang representatif unuk model adalah $35^{\circ}$, sehingga batang tarik Sd dan batang tekan SI dapat dipakai pipa $\varnothing 711,2 \mathrm{~mm}$, sedangkan untuk batang tekan Sh dipakai pipa $\varnothing 1117,6 \mathrm{~mm}$.

\subsection{J umlah tiang reaksi/angker.}

a. Rancangan model meja beban rangka batang diletakkan pada 4 (empat) tumpuan tiang reaksi seperti pada gambar berikut :

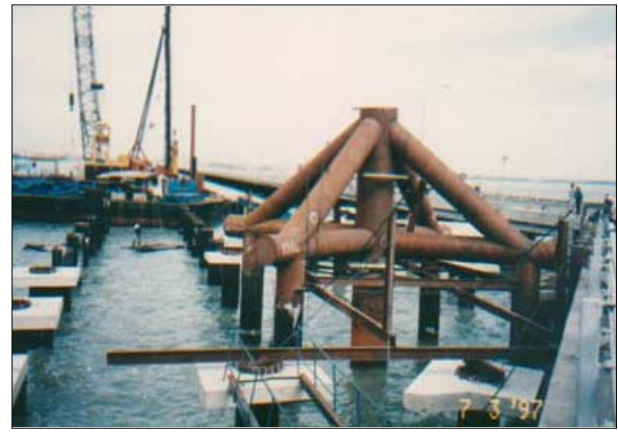

Gambar 5. Model Struktur Rangka ARF

b. Kekuatan tiang reaksi didasarkan pada beban 650 ton, dan dimensi tiang reaksi yang ada dilapangan adalah pipa baja $\varnothing$ $711,2 \mathrm{~mm}$ dengan panjang 70 meter.

c. Gaya tarik ultimate tiang reaksi didasarkan pada Meyerhoff Formula dan data Boring adalah:

$$
R d=\frac{1 \times 1.3}{5}+\frac{7 \times 63.7}{2}=497.8 \text { ton/pile }
$$

Safety factor, dengan jumlah tiang reaksi 4 buah adalah :

$$
n=\frac{4 \times 497.8 \times 2 / 3}{650}=2.042(\text { safe })
$$

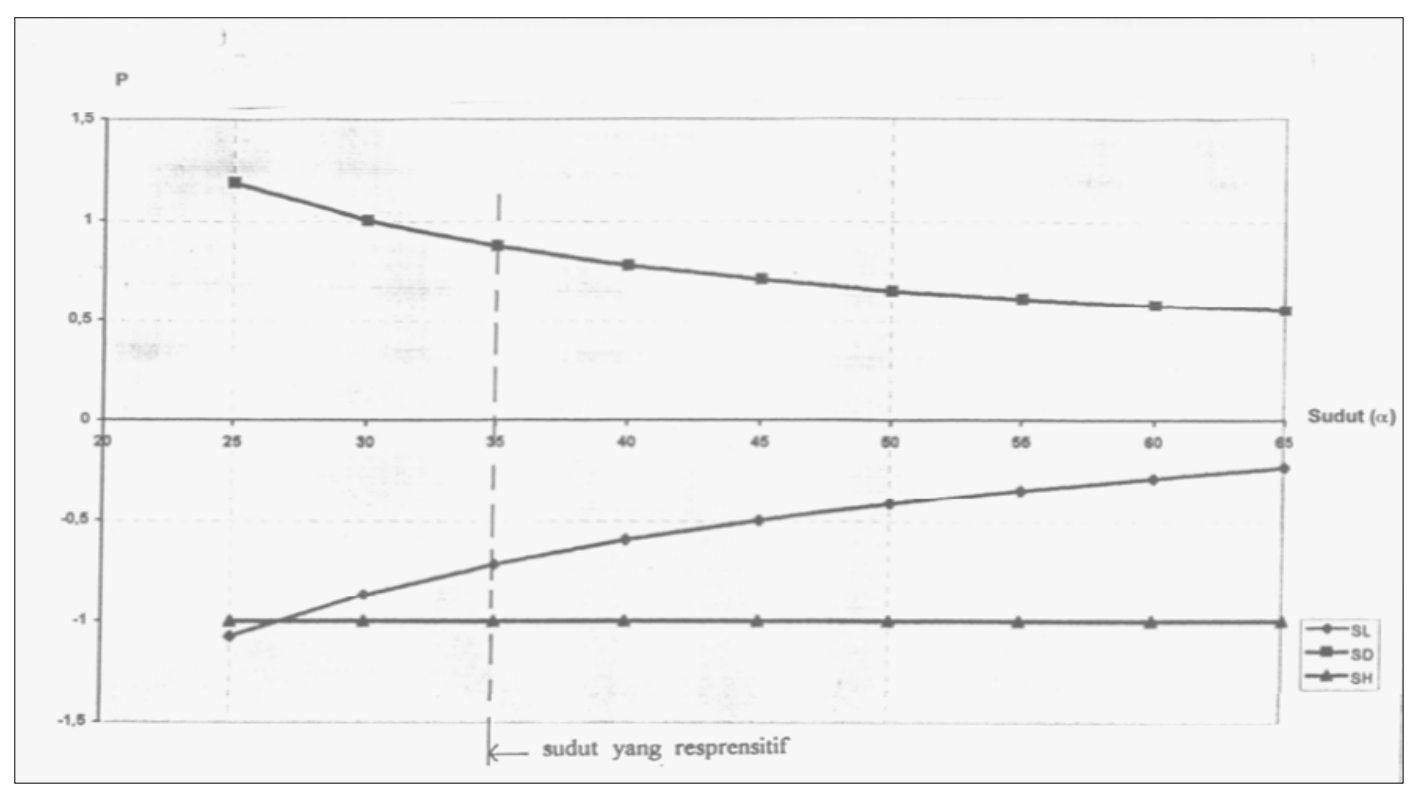

Grafik 5. Hubungan Beban P dan Sudut a 


\subsection{Lendutan Pada Struktur Rangka Meja Beban.}

Dengan meletakkan beban uji $\mathrm{P}=650$ ton di titik $D$ pada model, dilakukan perhitungan deformasi rangka batang di titik $D$ dengan menggunakan Metode $\alpha$ koefisien dengan anggapan berat sendiri rangka diabaikan. Hasil perhitungan deformasi dapat dilihat pada tabel 4.2 berkut.

Tabel 1. Perhitungan deformasi dengan metode $\alpha$ koefisien

\begin{tabular}{|c|l|c|c|c|}
\hline No & \multicolumn{1}{|c|}{ Uraian } & \multicolumn{3}{|c|}{ Batang } \\
\cline { 3 - 5 } & & SD & SL & SH \\
\hline 1 & Gaya batang P $(\mathrm{kg})$ & +140804 & -114996 & -650000 \\
\hline 2 & Panjang batang L $(\mathrm{cm})$ & 518,40 & 424,60 & 297,20 \\
\hline 3 & Luas penampang A (cm2) & 531,44 & 531,44 & 1114,61 \\
\hline 4 & $\begin{array}{l}\text { Elastisitas bahan } \\
\text { E }(\mathrm{kg} / \mathrm{cm} 2)\end{array}$ & $2,1 \times 106$ & $2,1 \times 106$ & $2,1 \times 106$ \\
\hline 5 & $\Delta \mathrm{L}=\mathrm{PL} / \mathrm{EA}(\mathrm{cm})$ & $+0,0654$ & $-0,04375$ & -0.0825 \\
\hline 6 & $\alpha$ untuk satu satuan & $+0,4355$ & $-0,3570$ & $-1,0000$ \\
\hline 7 & $\alpha \Delta . \mathrm{L}(\mathrm{cm})$ & $+0,0285$ & $+0,0156$ & $+0,0825$ \\
\hline \multicolumn{2}{|c|}{$\delta=\sum \alpha \Delta \mathrm{L}(\mathrm{cm})$} & \multicolumn{3}{|c|}{0.1266} \\
\hline
\end{tabular}

Dari hasil perhitungan deformasi di titik $D, \delta$ $=1.266 \mathrm{~mm}<25 \mathrm{~mm}$, sehingga disimpulkan rancangan struktur model dapat dipakai dan dibebani baban siklus sesuai dengan standar ASTM D 1143 - 18, untuk mengamati dan mengevaluasi stabilitas model tersebut.

\section{PENGUJ IAN RANCANGAN STRUKTUR DENGAN BEBAN SIKLUS}

\subsection{Standard Pengujian Pembebanan Pada Rancangan Struktur.}

Pembebanan siklus dilakukan 4 (empat) sesuai dengan Standard of ASTM D11443-81.

\subsection{Dimensi Rancangan Struktur ARF.}

Rancangan struktur ARF seperti pada gambar 6 , dengan variabel seperti pada tabel berikut:

Tabel 2. Variabel Rancangan ARF

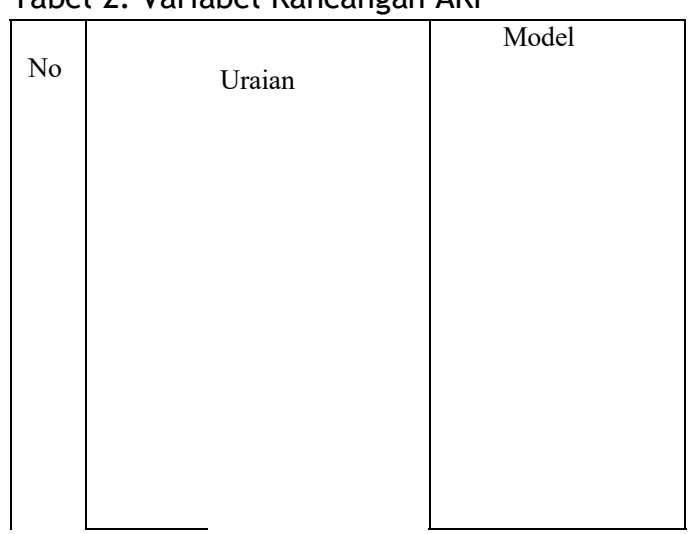

\section{HASIL PENGUJ IAN DAN ANALISA PEMBAHASAN}

\subsection{Hasil Pengujian}

Dari data hasil pengamatan pelaksanaan pembebanan, dapat digambarkan grafik hubungan antara waktu - beban dan deformasi pada tiang reaksi, rancangan model rangka meja beban (ARF), dan tiang uji seperti yang ditunjukkan pada gambar 6 .

\subsection{Analisa Pembahasan.}

Dari data-data hasil pengamatan riel deformasi dan gambar grafik (6), maka pada setiap tahapan siklus pembebanan dapat digam- barkan perilaku perubahan gerak/deformasi masing-masing komponen pada rancangan struktur rangka ARF, tiang uji, dan tiang reaksi pada setiap tahapan siklus pembebanan sebagai berikut :

A. Pada tahap pembebanan Siklus pertama Tabel 3. Deformasi teoritis \& riel tiang uji, tiang reaksi \& A.R.F

\begin{tabular}{|c|c|c|c|c|c|c|}
\hline \multirow{3}{*}{$\begin{array}{c}\text { Beban } \\
\text { Siklus } \\
\% \mathrm{P} \\
\end{array}$} & \multicolumn{6}{|c|}{ Deformasi $\Delta(\mathrm{mm})$} \\
\hline & \multicolumn{2}{|c|}{ Tiang uji } & \multicolumn{2}{|c|}{ Tiang reaksi } & \multicolumn{2}{|c|}{ Rangka ARF } \\
\hline & $\Delta \mathrm{tu}$ & $\Delta \mathrm{ru}$ & $\Delta \operatorname{tr}$ & $\Delta \mathrm{rr}$ & $\Delta \mathrm{Dt}$ & $\Delta \mathrm{Dr}$ \\
\hline 25 & -1.22 & -0.39 & +0.64 & +1.60 & +0.378 & 0 \\
\hline 50 & -2.44 & -2.20 & +1.28 & +2.80 & +0.757 & 0 \\
\hline 25 & -1.22 & -0.4 & +0.64 & +2.90 & & 0 \\
\hline 0 & 0 & -1.44 & 0 & +1.50 & 0 & 0 \\
\hline \multicolumn{7}{|c|}{$\begin{array}{l}\text { Sumber: Proyek Dermaga Peti Kemas Pelindo III. } \\
\text { Note: }\end{array}$} \\
\hline$\Delta \mathrm{t}$ & \multicolumn{6}{|c|}{$\begin{aligned}= & \text { Regangan } / \text { perpendekan pipa teoritis } \\
& (\Delta t=\mathrm{PL} / \mathrm{EI})\end{aligned}$} \\
\hline$\Delta \mathrm{r}$ & \multicolumn{6}{|c|}{$\begin{array}{l}=\text { Regangan } / \text { perpendekan riel sesuai } \\
\text { pengamatan. }\end{array}$} \\
\hline \multicolumn{7}{|c|}{ pengantatan. } \\
\hline \multicolumn{7}{|c|}{$\begin{array}{l}\Delta \mathrm{Dr}=\text { Deformasi riel pada titik } \mathrm{D} \text { rangka ARF } \\
+/-\quad=\text { Perpanjangan/perpendekan }\end{array}$} \\
\hline
\end{tabular}

Mengacu pada Tabel 3 dapat digambarkan perilaku deformasi ketiga komponen untuk percobaan loading test adalah Pada pembebanan awal sebesar $25 \%$ sampai $50 \%$ beban servis, tiang reaksi cenderung terangkat senilai $\Delta \mathrm{rr}=2.80$ $\mathrm{mm}$, masalah ini akibat adanya regangan tarik pipa baja tiang reaksi sebesar $\Delta \mathrm{tr}$ $=1.28 \mathrm{~mm}$, sedangkan sisanya senilai 1.52 $\mathrm{mm}$ disebabkan deformasi pada perletakan dongkrak hydraulic.

- Pada pengurangan beban (rebound) hingga $0 \%$, ternyata tiang reaksi tidak kembali pada posisi semula $(\Delta \mathrm{rr}=+1,50$ $\mathrm{mm})$. Hal ini diakibatkan oleh tiang uji setelah dilakukan penambahan beban mengalami penurunan sebesar $\Delta \mathrm{ru}=$ $1.44 \mathrm{~mm}$ yang diprediksi tiang uji mengalami tekuk dan pada saat 
pengurangan beban tiang uji kembali pada posisi semula, yang menghambat tiang reaksi ke posisi semula dan pada kondisi ini kondisi tanah masih stabil.

- Untuk rangka ARF pergerakannya mengikuti perilaku tiang uji dan tiang reaksi, akan tetapi deformasi riel rangka ARF secara individual nol ( $\delta D r$ $=0)$,

- Dan dapat diartikan rancangan struktur ARF cukup kaku dan stabil.

B. Pada tahap pembebanan Siklus kedua Tabel 4. Deformasi teoritis \& riel tiang uji, tiang reaksi \& rangka ARF

\begin{tabular}{|c|c|c|c|c|c|c|}
\hline Beban & \multicolumn{6}{|c|}{ Deformasi $\Delta(\mathrm{mm})$} \\
\cline { 2 - 7 } Siklus & Tiang uji & \multicolumn{2}{c|}{ Tiang reaksi } & Rangka ARF \\
\hline$\%$ P & $\Delta$ tu & $\Delta \mathrm{ru}$ & $\Delta$ tr & $\Delta \mathrm{rr}$ & $\delta$ D t & $\delta$ D r \\
\hline 25 & -1.22 & -0.105 & +0.64 & +1.90 & +0.378 & 0 \\
\hline 50 & -2.44 & -2.223 & +1.28 & +3.10 & +0.757 & 0 \\
\hline 75 & -3.67 & -5.695 & +1.92 & +4.40 & +1.031 & 0 \\
\hline 100 & -4.89 & -9.680 & +2.56 & +5.93 & +1.456 & 0 \\
\hline 75 & -3.67 & -9.108 & +1.92 & +6.10 & +1.031 & 0 \\
\hline 50 & -2.44 & -6.343 & +1.28 & +5.40 & +0.757 & 0 \\
\hline 25 & -1.22 & -2.200 & +0.64 & +4.30 & +0.378 & 0 \\
\hline 0 & 0 & -1.138 & 0 & +2.70 & 0 & 0 \\
\hline
\end{tabular}

Perilaku gerak tiang uji, tiang reaksi, dan rangka ARF akibat pembebanan dengan mengacu pada Tabel 4 adalah:

- Pada proses pembebanan 25-50-75$100 \% \mathrm{P}$ servis, tiang reaksi mengalami regangan riel yang makin besar dari
$\Delta \mathrm{rr}=+1.90 \mathrm{~mm}$ menjadi $\Delta \mathrm{rr}=+5.80$ $\mathrm{mm}$, sedangkan tiang uji mengalami perpendekan mencapai $\Delta \mathrm{ru}=-9.68$ $\mathrm{mm}$, sehingga dapat diprediksi bahwa selama peningkatan beban tiang uji mengalami perpendekan dan tekuk sesuai dengan Hukum HOOKE, karena kondisi tanah masih stabil.

- Pada proses pengurangan beban dari 100-75-50-25-0\% P servis, tiang uji mengalami peregangan sebasar $\Delta+=$ $|(-9.68)-(1.138)|=|8.542| \mathrm{mm}$, sedangkan tiang reaksi mengalami perpendekan sebesar $\Delta-=\mid(+5.93)$ $(+1.50)|=| 4.43 \mid \mathrm{mm}$. Dari nilai mutlak $\Delta+>\Delta$-, dapat diprediksi bahwa tiang reaksi dan tiang uji tidak dapat kembali pada posisi semula karena saling menghambat proses peregangan tiang uji dan perpendekan tiang reaksi.

- Untuk rangka ARF deformasi riel ( $\delta D r$ = 0) selama proses pembebanan, sehingga pergerakan akibat perilaku perubahan deformasi pada tiang uji dan tiang reaksi tidak mempengaruhi stabilitas rangka ARF, yang berarti strukrur ARF masih cukup kaku dan stabil pada beban $P$ servis $100 \%$.

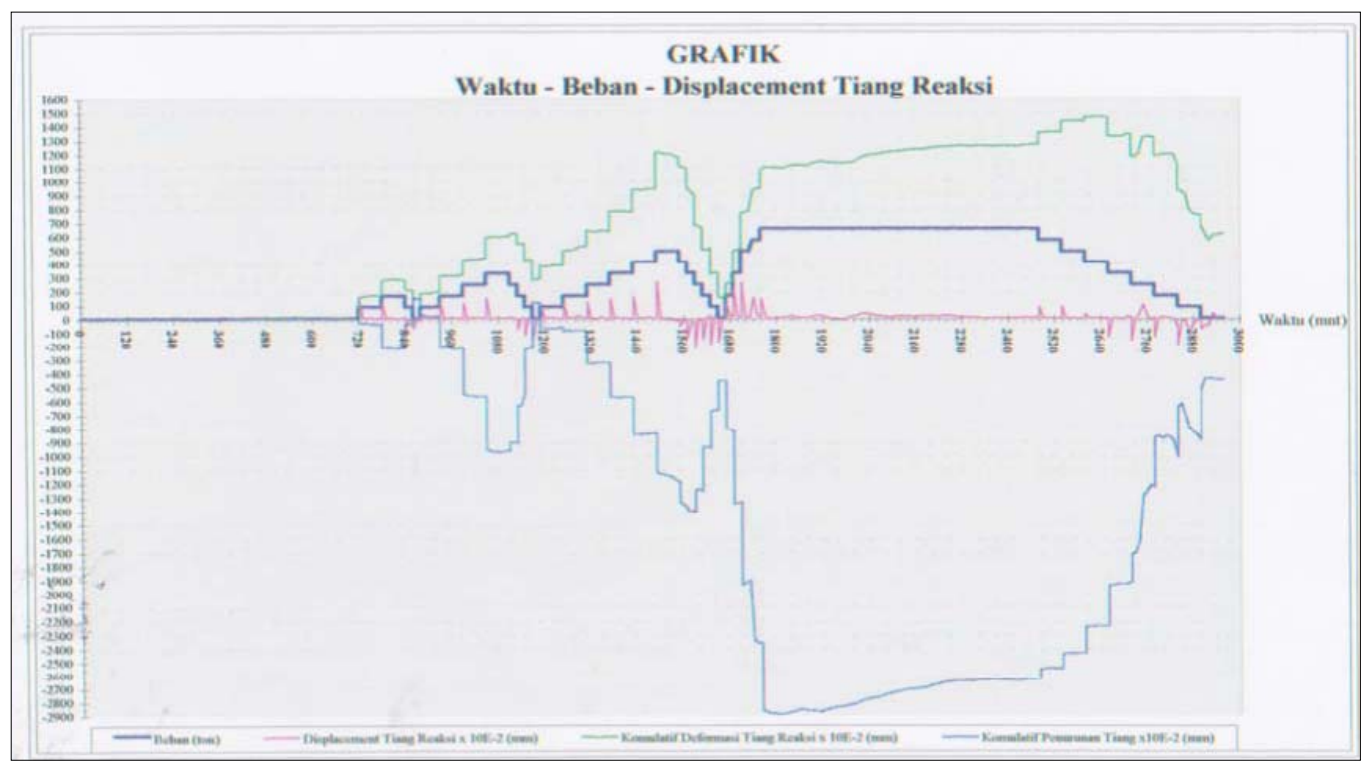

Gambar 6. Grafik Hubungan Waktu-Beban-Displacement Tiang Reaksi 
C. Pada tahap pembebanan Siklus ketiga

Tabel 5 Deformasi teoritis \& riel tiang

uji,tiang reaksi \& rangka ARF

\begin{tabular}{|c|c|c|c|c|c|c|}
\hline Beban & \multicolumn{6}{|c|}{ Deformasi $\Delta(\mathrm{mm})$} \\
\cline { 2 - 7 } Siklus & Tiang uji & \multicolumn{2}{|c|}{ Tiang reaksi } & Rangka ARF \\
\hline$\% \mathrm{P}$ & $\Delta \mathrm{tu}$ & $\Delta \mathrm{ru}$ & $\Delta \mathrm{tr}$ & $\Delta \mathrm{rr}$ & $\delta \mathrm{D} \mathrm{t}$ & $\delta \mathrm{Dr}$ \\
\hline 25 & -1.22 & -0.687 & +0.64 & +3.90 & +0.378 & 0 \\
\hline 50 & -2.44 & -0.870 & +1.28 & +5.70 & +0.757 & 0 \\
\hline 75 & -3.67 & -3.320 & +1.92 & +6.40 & +1.031 & 0 \\
\hline 100 & -4.89 & -5.758 & +2.56 & +7.70 & +1.456 & 0 \\
\hline 125 & -6.11 & -8.432 & +3.20 & +9.70 & +1.630 & 0 \\
\hline 150 & -7.33 & -11.958 & +3.85 & +9.20 & +1.957 & 0 \\
\hline 125 & -6.11 & -13.895 & +3.20 & +11.80 & +1.630 & 0 \\
\hline 100 & -4.89 & -14.145 & +2.56 & +9.10 & +1.456 & 0 \\
\hline 75 & -3.67 & -12.608 & +1.92 & +6.60 & +1.031 & 0 \\
\hline 50 & -2.44 & -9.533 & +1.28 & +5.20 & +0.757 & 0 \\
\hline 25 & -1.22 & -6.715 & +0.64 & +3.40 & +0.378 & 0 \\
\hline 0 & 0 & -4.958 & 0 & +1.50 & 0 & 0 \\
\hline Sumber: Proyek Dermaga Peti Kemas Pelindo III
\end{tabular}

Perilaku gerak tiang uji,tiang reaksi, dan rangka ARF akibat pembebanan dengan mengacu pada Tabel 5 adalah :

- Dengan kenaikan interval pembebanan sebesr $25 \%$ dengan beban maksimum $150 \%$, tiang uji mengalami penurunan sebesar $\Delta \mathrm{r}=-11.958 \mathrm{~mm}$ dan tiang reaksi mengalami kenaikan sebesar $\Delta r=+11.80 \mathrm{~mm}$, sehingga tiang uji dan tiang reaksi mengalami deformasi yang mendekati sama dan berbanding terbalik.

- Dengan penurunan beban dengan interval $25 \%$ sampai $0 \%$, tiang uji mengalami peregangan sebesar $\Delta^{+}=$ $|(-11,958)-(-1.138)|=|10.82| \mathrm{mm}$ dan tiang reaksi mengalami perpendekan sebesar $\Delta^{-}=|(+11.80)-(+1.50)|=|10.30|$ $\mathrm{mm}$. Dari nilai $\Delta+>\Delta-$, sehingga tiang reaksi terhambat oleh tiang uji untuk kembali pada posisi semula.

- Untuk rangka ARF akibat perubahan deformasi dari tiang uji dan tiang reaksi, tidak mengalami deformasi $(\delta \mathrm{Dr}=0)$ selama proses pembebanan $150 \%$.

D. Pada tahap pembebanan Siklus keempat

Perilaku gerak tiang uji, tiang reaksi, dan rangka ARF dengan mengacu pada tabel 6 adalah:

- Tiang uji sejak dibebani bertahap dengan interval beban 50\% sampai mencapai 200\%, mengalami perpendekan maksimum sebesar $\Delta \mathrm{ru}=$ $28.89 \mathrm{~mm}>-\Delta=25 \mathrm{~mm}-$ yang meningkat seolah-olah proporsional dengan beban siklus yang diberikan dan pada beban kritis/beban kondisi tanah belum mengalami kelongsoran (failure) dan panjang tiang 70 meter,maka dapat diprediksi tiang uji menekuk kesamping untuk setiap arah akibat gaya tekan.

Tabel 6. Deformasi teoritis \& riel tiang uji, tiang reaksi \& rangka ARF

\begin{tabular}{|c|c|c|c|c|c|c|}
\hline Beban & \multicolumn{6}{|c|}{ Deformasi $\Delta(\mathrm{mm})$} \\
\cline { 2 - 7 } Siklus & \multicolumn{2}{|c|}{ Tiang uji } & \multicolumn{2}{|c|}{ Tiang reaksi } & \multicolumn{2}{c|}{ Rangka ARF } \\
\hline$\% \mathrm{P}$ & $\Delta \mathrm{tu}$ & $\Delta \mathrm{ru}$ & $\Delta \mathrm{tr}$ & $\Delta \mathrm{rr}$ & $\delta \mathrm{D} \mathrm{t}$ & $\delta \mathrm{D} \mathrm{r}$ \\
\hline 50 & -2.44 & -8.270 & +1.28 & +2.60 & +0.757 & 0.000 \\
\hline 100 & -4.89 & -13.37 & +2.56 & +5.00 & +1.456 & 0.000 \\
\hline 150 & -7.33 & -19.07 & +3.85 & +7.60 & +1.957 & 0.000 \\
\hline 175 & -8.56 & -23.65 & +4.49 & +9.40 & +2.282 & 0.000 \\
\hline 200 & -9.78 & -28.89 & +5.13 & +11.10 & +2.585 & +0.022 \\
\hline 200 & -9.78 & -28.65 & +5.13 & +11.00 & +2.585 & +0.022 \\
\hline 200 & -9.78 & -28.15 & +5.13 & +11.40 & +2.585 & +0.022 \\
\hline 200 & -9.78 & -27.21 & +5.13 & +12.50 & +2.585 & +0.022 \\
\hline 200 & -9.78 & -26.31 & +5.13 & +13.40 & +2.585 & +0.022 \\
\hline 175 & -8.56 & -25.47 & +4.49 & +14.40 & +2.282 & +0.022 \\
\hline 150 & -7.37 & -24.36 & +3.85 & +14.60 & +1.957 & +0.022 \\
\hline 125 & -6.11 & -22.40 & +3.20 & +13.60 & +1.630 & +0.022 \\
\hline 100 & -4.89 & -19.12 & +2.56 & +11.90 & +1.456 & +0.022 \\
\hline 75 & -3.67 & -12.32 & +1.92 & +13.20 & +1.031 & +0.022 \\
\hline 50 & -2.44 & -10.18 & +1.28 & +11.90 & +0.757 & +0.022 \\
\hline 25 & -1.22 & -8.92 & +0.64 & +9.20 & +0.378 & +0.022 \\
\hline 0 & 0 & -4.52 & 0 & +6.00 & 0 & +0.022 \\
\hline Sumber $:$ Proyek Dermaga Peti Kemas Pelindo & III
\end{tabular}

- Pada pembebanan final, ternyata tiang uji dan tiang reaksi tidak dapat kembali pada posisi awal, disebabkan adanya selisih nilai regangan tiang uji dan perpendekan tiang reaksi tidak sama $\left(\Delta^{+}=23.77 \mathrm{~mm}>\Delta^{-}=11.90\right.$ $\mathrm{mm})$.

- Pada beban maksimum $200 \%$, rangka ARF masih stabil karena Nilai $\delta D r=$ $0.022 \mathrm{~mm}<-\delta \mathrm{D}=25 \mathrm{~mm}$, sehingga ditinjau dari kestabilan struktur, rangka strukur cukup kaku dan stabil.

\section{KESIMPULAN}

1. Dari kondisi perilaku gerak dan deformasi pada tiang uji dan tiang reaksi selama pembebanan siklus kesatu sampai keempat, membuktikan bahwa rancangan struktur ARF tetap stabil.

2. Dari evaluasi perilaku perubahan deformasi rancangan struktur ARF selama proses pembebanan siklus kesatu sampai keempat dengan mengamati besarnya $\delta \mathrm{Dr}=0$ pada siklus kesatu sampai ketiga, dan $(\delta \mathrm{Dr}=0.022 \mathrm{~mm})<$ $(\delta D=25 \mathrm{~mm})$ pada siklus keempat, 
membuktikan bahwa rancangan struktur ARF cukup kaku rangka batangnya.

3. Rancangan struktur ARF dapat memprediksi, kemampuan besarnya gaya tarik tiang pancang baja $\varnothing 711,2$ $\mathrm{mm}$ dengan membagi beban maksimun dengan jumlah tiang reaksi yang diperkirakan senilai $\mathrm{P}=162.50$ ton.

\section{DAFTAR ACUAN}

Acuan yang dipakai untuk penulisan artikel ini antara lain:

ASTM 1143 - 81.May 1994. Standard Test Method for Piles Under Static Axial Compressive Load.
Popov.1978. Mechanics of Materials $2^{\text {nd }}$ edition. Prentice-Hall Inc.

Soewarno.1980. Mekanika Teknik, J ilidl, II, III. Gajah Mada Press.

Tomlinson.1977. Pile Design and Construction Practice. Printed by Garden City Press Limited, First Publihed.

Wawan Witarman.1995. Pengujian Beban Pondasi Tiang Pancang Abutment I Jembatan Ciamis Cirebon.Departemen P.U. 